\title{
3 Herbert Marcuse: One-Dimensional Man and the technological veil
}

If Marcuse already seems to come from another era, this may be due less to the implausibility of his speculative projections than to the increasing resignation of intellectuals in the West, less and less able to imagine a truly radical break with the present.

(Feenberg, “The Bias of Technology”, 1988, p. 254)

\subsection{Introduction: Marcuse the Marxist}

Providing an overview of Marx's influence on reflections on technology in the years following the publication of Capital would be, both conceptually and historically, a bewildering task. Fortunately, it is one we can largely bypass when exploring Marcuse's continuation of Marx's thought on technology. In the early 1930s, Marcuse wrote a thorough review of Marx's, then newly published, early manuscripts, which helped set the reception of Marx's thought back on the path largely identical to that presented in chapter two. A primary concern for much political thought at the time when Marcuse started writing was the question of revolution. In 1918, Marcuse had played his small part in the ultimately failed revolutionary activities in Berlin, being asked to take up arms against right-wing snipers. In the latter half of the 1960s he was a prominent, star-like figure among The New Left, the counterculture of the San Francisco hippies, and the students with their joint and failed revolution in Paris. One-Dimensional Man and Eros and Civilization, the latter with a new "Political Preface", were published in paperback versions in 1966, and in particular the former had a wide readership.

In the year of the crash at the New York Stock Exchange, Henryk Grossman published The Law of Accumulation and Collapse of the Capitalist System (1929). While not being specific in any way about the timing of an actual demise of capitalism, he confronted reasons for thinking that capitalism could go on indefinitely. He emphasised the role of workers in seizing the right moment and becoming conscious agents in history when the circumstances were appropriate. Grossman was then the chief economist at the Marxist Institute for Social Research, which was still located in Frankfurt when Marcuse joined it in 1932, after studying in Freiburg under Heidegger. At the institute, Marcuse worked with Horkheimer on a concept of critical theory that would remain central to his own work. Consciousness and agency of the workers was exactly the problem 
in at least two fundamental ways. Firstly, their consciousness, and secondly, their status as a class.

Concerning the first problem, Lukács had argued that "the rational mechanization extends right into the worker's soul” (1923, p. 98), and this is a theme that reverberated with Marcuse, especially as he went on to study forms of propaganda during WW2. Lukács' analysis of Marx, carried out in the light of Hegel's Phenomenology of Spirit, was vindicated when Marx's early Economic and Philosophical Manuscripts were published in the late 20s. The manuscripts take us to one of Marcuse's early writings, which was also one of the first essays on the newly discovered manuscripts. Marcuse's exposition of Marx was one that placed the concept of alienation at the centre of a Marxist understanding of society and the worker. His was the "humanist" Marx, rather than the scientific Marx and Engels, that had dominated much of Marx's reception and development. The background for Marcuse's work on Reason and Revolution (1941) had been to emphasise the Hegelian, dialectic aspects of Marx at the cost of a presumed scientific one. "The soul of the worker" was the foundation of Marcuse's concern in the decades to come, and concepts of alienation, production, and technology continued to play a substantial role throughout, as Marcuse responded to what had long been known as "the crisis of Marxism": the absence of a revolutionary change in society, in some way along the lines envisaged by Marx. Like Grossman, Marcuse did not project any specific time for a revolution. Andrew Feenberg, a student of Marcuse's, recalls how Marcuse "elaborated the conditions of its possibility" (2010, p. 241). Late in his work, Marcuse increasingly drew on aesthetic thinking and saw a change in sensibility as a prerequisite for such a change.

We approach Marcuse as someone responding to the lack of a new stage of society and someone who, in his most influential work, One-Dimensional Man, clearly perceives Marx's focus on labour in his understanding of man: "we live and die rationally and productively" (ODM, p. 149). The concern is seen in the subtitle to One-Dimensional Man, "studies in the ideology of Advanced Industrial Society", and is expressed in his 1960 piece, From Ontology to Technology: "Up to the present, technical progress remains the progress of an alienated labor, of a repressive productivity" (2011a, p. 138). Having read Husserl's Crisis of European Sciences and Transcendental Phenomenology and studied under Heidegger in the late 1920s, phenomenology remained a resource for Marcuse in thinking about science, technology and the human subject, and it continued to be visible in his response to the crisis. ${ }^{1}$ Further, Freud was relied upon when thinking

1 In particular, Marcuse's concept of the technological a priori in chapter 6 of ODM, has strong 
about the human subject, instincts, needs, and mechanisms of repression. Yet, Marcuse's 1932 review reiterates the themes that were explored in chapter two and that also make up the main axis of Marcuse's response to the crisis: The human essence (Wesen) is closely tied up with the idea of objectification through labour, but in a capitalist society, “...the existence of man does not become, in estranged labor, the "means" for his self-realisation. The reverse happens: man's self becomes a means for his mere existence” (2005b, p. 104).

Marcuse reminded the reader that Marx's writings were no mere exercise in philosophy, but the "foundation of a theory of revolution" (2005b, p. 104) with practical intent. He further addressed the conundrum that we encountered in Marx, of combining two ideas: first, that of an essence in the labourer that is being thwarted by technological means - instruments of labour eventually wielded by the machine. Second, the overall dialectical outlook, according to which reality - essences - develops through opposition and sublation: "If historical facticity thus reveals the total inversion of all the conditions given in the determination of the human essence, does it not prove that this determination lacks content and sense, and that it is only an idealistic abstraction, which does violence to historical reality?” (2005b, p. 105). Marcuse suggested that this should initially be seen as a matter of Marx's fighting on different fronts. For example, appeal to a human Wesen served as a tool of critique in interaction with the "bourgeois political economy" and as a more practically oriented platform for opposing Hegelian-inspired forms of idealism. More fundamentally, Marcuse insists that "[w]e are no longer dealing with an abstract human essence, which remains equally valid at every stage of concrete history, but with an essence that can be defined in history and only in history" (2005b, p. 105, Marcuse's emphasis). Focus on the human essence and its material, real-life realisation (existence) is the driver for revolution: "It is precisely the persistent focus on the essence of man that becomes the inexorable impulse for the initiation of radical revolution. The factual situation of capitalism is characterised not merely by economic or political crisis but by a catastrophe of the human essence" (Marcuse 2005b, p. 106). This dialectic approach to understanding the human subject and world history is a constant in Marcuse's thinking from the early 30s to the 70s, though talk of essences is less frequent in Marcuse's more mature writing. Dialectics play out at the level of the individual: "Judged in the light of their essence and idea, men and things exist as other than they are; consequently;

affinities with Heidegger's notion of das Gestell (See chapter five). The Heideggerian aspects of Marcuse's thinking have been explored by Wolin (2001) and in more writings, by Feenberg (e.g. 2005). 
thought contradicts that which is (given), opposes its truth to that of the given reality" (ODM, p. 136). Concerning world history, seen from the viewpoint of modes of production, dialectics is also in play: "The established rationality becomes irrational when, in the course of its internal development, the potentialities of the system have outgrown its institutions” (ODM, p. $225 \mathrm{f}$., his emphasis). Yet, to Marcuse there is no necessity to this development. It must be a matter of free, human consciousness. "As historical process, the dialectical process involves consciousness: recognition and seizure of the liberating potentialities. Thus, it involves freedom" (ODM, p. 227).

More than three decades after writing his review of Marx's manuscript, at a 1966 Symposium held at the University of Notre Dame, Marcuse (1967b) returns to the question of the obsolescence of Marxism. He identifies five propositions, of which he considers the first four to have been corroborated by societal developments: social relationships are governed by exchange, rather than use-value; satisfaction of human needs is a by-product of production driven by profits; capitalism is subject to contradictions: between the social character of production and ownership of the means of production and between growing productivity of labour and its use for repression and destruction in the form of a cycle of wars, wasteful production and destruction of productive powers and, finally, the need for labouring classes to break this cycle by seizing the means of production. That is to say, at this late stage, Marcuse considers Marxism anything but obsolete. Later yet, in Counterrevolution and Revolt, Marcuse warns against a "mechanistic repetition of basic vocabulary" (1972, p. 34). The concepts used by a Marxist are themselves historical and must be applied anew to grasp the actual contradictions in society. Accordingly, Marcuse demonstrates in his writings a wide acquaintance with empirically informed analyses of work life and technologies. He also had intimate knowledge of bureaucratic and political modes of thought from his seven years of work for the US Office of War Information, the predecessor of the CIA. At the Office of Strategic Services, he had the task of analysing propaganda in Germany.

Marcuse suggested that the concept of "the working class" and its agency had lost traction as an analytical tool for thinking about the advent of a revolution. Genuine opposition had become "isolated from the masses and from the majority of organized labour” (1972, p. 57). The presumed source of opposition, the working class, had become integrated in the ideology of the majority, which was the focus of Marcuse's work, as suggested by the subtitle of his most popular book: Studies in the ideology of advanced industrial society. Accordingly, the concern for, and expectations towards, the "soul of the worker" is transformed. The strata of humans that are subject to the demands of the machine are vastly expanded, and the working class loses the meaning it had in Marx's analyses. 
Rather, Marx's focus on the machine is what frequently reappears in Marcuse's thinking: "The enlarged universe of exploitation is a totality of machines human, economic, political, military, education” (1972, p. 13).

Discussion of production and progress is another Marxist constant. Marcuse did join many others in scathing criticisms of the emergent consumer society the economically necessary flipside of an enlarged productive force. As ODM is published, The Carousel of Progress is put on display at Progressland of the New York World's Fair. Designed and built by Walt Disney and General Electric, Progressland was an audio-animatronic celebration of the democratisation of consumption and domestication of progress that had characterised the second industrial revolution. Progress had moved into the home, and the spectator - to the tune of The Sherman Brothers' "There is a great big, beautiful tomorrow" is transported to four different scenes of a typical, American home, with evernew appliances. ${ }^{2}$ Such an outlook, which saw an intimate relation between progress and technology, had been emphasised by historian Charles A. Beard in the 1920s, and already then reflected a widespread, American sentiment. ${ }^{3}$ The close tie between consumption, technology and progress was an easy target for intellectuals. However, while Marcuse had a keen eye for the debilitating effects of consumption on the possibility of a critical, history-moving agent, he insisted: “'Consumer society' is a misnomer of the first order, for rarely has society so systematically been organized in the interests which control production" (1972, p. 23).

In what follows, the exposition of the place of technology in Marcuse's thought is framed by way of relatively coarse interpretive categories: the notion of instrumentalism, and the distinction between optimism and pessimism about technology. Regarding the latter distinction, we saw both tendencies feature in Marx's analysis of technology. The story of the development of technology was the story of increased alienation of human subjects and various forms of bodily, material and spiritual misery. Alongside this, one can discern a far more positive outlook, emphasising how technologies can at least offer the conditions for genuine progress - advancement, reward and advantages in different spheres of life.

\footnotetext{
2 See Roderick (2016) and Weiner (1997) for analyses of the Carousel of Progress. Still running five decades later at the Walt Disney World Resort, the Carousel of Progress has mainly been subject of academic attention for the view of women that can be seen in its different reiterations over the years.

3 See e.g. Beard (1927) for an original expression, and Marx (2010) and Nye (1996) for accounts of this sentiment.
} 
The distinction between optimists and pessimists remains extremely pervasive. ${ }^{4}$ While van der Laan (2016) marshals substantial evidence that the positive outlook on technology is dominant, this judgement relies on casting the net wider historically and intellectually - than the immediate cultural and intellectual setting of Marcuse's philosophy of technology, and wider than philosophy of technology in the latter part of the $20^{\text {th }}$ century.

The tenor of Marcuse's reflections on technology was certainly negative. This is only reinforced if one places too great an emphasis on his intellectual affiliation with members of the Institute for Social Research, where Adorno and Horkheimer had offered their famed criticisms of instrumental reason and enlightenment. Pessimistic views of technology reverberated with philosophical contemporaries of Marcuse's, such as Ellul and Mumford. The understanding that Marcuse was a pessimist is readily gleaned from large parts of ODM. At a late stage of his academic career, this is the work that propelled him into wider fame and made him a renowned figure among The New Left. His academic home, however, did not take up his reflections on technology to any great extent. As Habermas carried forward the intellectual movement of the Frankfurt school and its critical theory, the question of technology seemed largely relegated to the question of the proper bounds of a rational system with a logic independent of that of the lifeworld. ${ }^{5}$ As is explored below, Marcuse's pessimism had a steady counterweight in optimistic strands in his thought, constantly searching for avenues of a qualitative change in our relationship with the productive apparatus of advanced, industrial society. One that would mean using technology as a means of liberation, not domination.

The first interpretive tool, instrumentalism, is also offered a key role in numerous discussions of technology, though often as a whipping boy. In this context, the concept of instrumentalism is best conveyed by prefixing "instrument" with "mere". As such, instrumentalism as a position is frequently contrasted

4 The presentations of philosophy of technology in Tiles \& Oberdiek (1995), Dusek (2006) and van der Laan (2016) rely on the distinction. Thierer (2010) uses it to understand and categorise academic and popular responses to widespread internet use.

5 Andrew Feenberg has, in particular, been critical of this omission: "I base my [criticism] on the peculiar historical situation in which the most powerful modernity theory completely ignored the growing challenge to the technological underpinnings of modernity. [...] My critique of Habermas emphasizes two extraordinary lacunae in his theory - the failure to include technology and the absence of a theory of the bias of rationality. The role of design is at issue in both but absent from Habermas' theory. The exclusion of technology is indefensible” (2017, p. 44). A collection of essays published in celebration of the $50^{\text {th }}$ anniversary of the publication of ODM offers the topic of technology scant attention (Maley, 2017). Below, we return to the issue of design as we discuss Marcuse's challenge to value sensitive design. 
with positions that insist that we cannot view technologies as mere means to certain ends, set by a freely acting agent. In spite of their appearance as mere tools, one must realise that they, in certain ways, can embody values or somehow exhibit agency. A version of this thought is explored in chapter 4 on Langdon Winner.

\subsection{Marcuse's pessimism: one-dimensional machine man and the happy consciousness}

From Marcuse's early essays, such as his 1941 "Some Social Implications of Modern Technology", through his 1960 "From ontology and technology" (2011a) and to his One Dimensional Man, a pessimistic account of man's relation with technology clearly emerges. As I shall see, this is an imprecise formulation, as Marcuse did not consider man separate from technology, but only from technics. The distinction between technics and technology is not one that Marcuse maintained consistently, but one that I will suggest underlies his more positive outlook on technology in particular. The bare-boned structure of Marcuse's tale of pessimism, one I put more flesh on below, is as follows: something is spread, by means of something, to something.

A form of rationality informed by the workings of a machine, spreads to the human subject in spheres other than those traditionally associated with work and production. In doing so, it dominates other forms of rationality, most importantly ones that allow the human subject to take a reasoned and critical stance on external authorities. Further, it spreads to spheres of life that have otherwise been ruled by other norms of rationality (e.g. politics), or arguably, have been ruled by no form of rationality at all. The mechanisms by means of which this had been achieved in the affluent USA, where Marcuse wrote, are themselves shaped by the advent of new technologies, predominantly those used in mass advertisement and forms of behaviour analysis and modification. The end result of this process is that alienation, the driver of historical development, is utterly stunted in the happy consciousness.

Marcuse offers a grand historical narrative that ties the enlightenment to the spread of new technologies, which then "turn around" and thwart the rational, critical subject. He suggests: "In the course of the technological process a new rationality and new standards of individuality have spread over society, different from and even opposed to those which initiated the march of technology" (1998, p. 42). Marcuse suggests that the development of technologies that had continued into the $20^{\text {th }}$ century was instigated by a class of citizens who held an ideal of being subject to no external constraints, but only to those derived 
from their rationality. Setting themselves beyond the immediate demands of the institutions of authority in surrounding society, these individuals would pursue self-interest on the premise that the self was rational, in some measure unlike norms and values of societal and religious institutions surrounding him. Kant offered perhaps the most famous expositions of this enlightened individual in his Answer to the question: What is enlightenment? where he pitted the courage of the reasoning individual against external norms.

Relying on ideas formulated by Veblen (1922) and empirical data from the work of the American Temporary National Committee, Marcuse positions technology as a threat to man's intellectual autonomy and ability to voice his own critical ideas. ${ }^{6}$ To Marcuse, the liberalist societal framework required for the flourishing of the critical, rational individual had become one of renewed repression, now in the form of machinery utilised in the competition that dominates the capitalist mode of production. The rational and autonomous individual had become the efficient individual, whose "performance is motivated, guided and measured by standards external to him, standards pertaining to predetermined tasks and functions" (1998, p. 45).

These standards are informed by what Marcuse follows Veblen in calling a matter-of-factness derived from the machine process. While Marcuse's enlightened, $17^{\text {th }}$ and $18^{\text {th }}$ century middle-class citizen fought external norms with their own rationality and will - attitudes that Marcuse suggests were integral to the beginning of the "march of technology" - the machine process now appears as the embodiment of rationality: "In manipulating the machine, man learns that obedience to the directions is the only way to obtain desired results. Getting along is identical with adjustment to the apparatus. There is no room for autonomy" (1998, p. 46). Crucial to this process having taken place is the idea of spheres of life and their invasion by machine rationality in the form of "efficient compliance". The reader may be better acquainted with the very similar idea that informs Walzer's Spheres of Justice (Walzer, 1983) and, as mentioned, Habermas also worked with a version of this idea. Marcuse offers no clear definition of spheres, but lists: "libido..., offices, schools, assemblies and, finally, in the realm of relaxation and entertainment” (1998, p. 47 f). In ODM, the categorisation can be seen in terms of the structure of the book: subjectivity (the "unhappy consciousness" becoming happy), intersubjectivity ("discourse"), science, philosophy, and political life are the spheres where matter-of-factness leads to a heter-

6 As explored by Eric Schatzberg (2018) and earlier, Leo Marx (1997), Veblen was a central figure in making the concept "technology" available and central for American social theory. Having, in the early 1900s, transformed the concept from a German use of "Technik", Veblen placed the concept in the context of criticising some forms of capitalism. 
onomous reproduction of the existing order, rather than a subject that projects its own critical plan, relying on its inherent reason.

For example, in extension of the use of the words "soul" and "alienation" that were appealed to in the introduction of this chapter, Marcuse took aim at ordinary language philosophy in its attempt to analyse this kind of language in a way that would, in Wittgenstein's terms, leave "everything as it is" and remain with description. To speak of soul carries a critical potential" ${ }^{7}$, and this aspect was largely absent when the concept was treated by philosophers like Ryle and Wittgenstein. They were content to remain with much simpler, supposedly everyday types of language, such as "the broom is in the corner". To Wittgenstein, the task of philosophy was therapeutic - "to give philosophy peace", and this, Marcuse considered an abject failure. The language with which ordinary people think, discuss and project possibilities is the language of "advertisements, movies, politicians and bestsellers” (ODM, p. 198). To gloss over how "the universe of thought and practice in which [people] live is a universe of manipulated contradictions" (ODM, p. 198) is for philosophy to become one-dimensional.

This process of the spread of matter-of-factness and machine behaviour is not experienced by the worker as an encroachment of something external upon the rationality of the individual. Adjusting and letting oneself be adjusted in different spheres of life has the clear appearance of being rational, or as Marcuse puts it summarily and dialectically in One-Dimensional Man: "The most vexing aspects of advanced industrial civilization: the rational character of its irrationality" (ODM, p. 11). Such contradictory statements are found predominantly in the later works of Marcuse and they should be seen as Marcuse's attempts at "jumpstarting" a dialectic process in society and subjectivity, one that would otherwise appear entirely arrested in the happy consciousness. Prescient of the extreme focus on privacy that has persisted with developments in informational technologies and forms of capitalism associated with it, Marcuse spoke of a private sphere being mobilised for mass production. ${ }^{8}$ He saw in thinkers, as diverse as David Hume and William James, the understanding that social forces associated with large-scale enterprises that emphasise competitiveness would prevail. As a consequence, "individualism took on more of the overtones

7 It is attested by the American title of the philosophically informed criticism of work: Shop Class as Soulcraft: An Inquiry into the value of Work (Crawford, 2009).

8 Beniger (1986) argued that the technological developments described by Marx prepared the ground for the possibilities of control inherent in an information society. Zuboff's (2015) concept of surveillance capitalism highlights new avenues of capitalist production, as it encroaches on informational privacy with a view to production of knowledge from "raw material" - data. 
of resignation" with individualism becoming "glorification of smallness, privacy and self-limitation” (1998, p. 60).

This is the picture of humans in industrial societies sketched out in 1941, and in many ways painted with more bite and irony in ODM:

\begin{abstract}
In this universe, technology also provides the great rationalization of the unfreedom of man and demonstrates the "technical" impossibility of being autonomous, of determining one's own life. For this unfreedom appears neither as irrational nor as political, but rather as submission to the technical apparatus which enlarges the comforts of life and increases the productivity of labor. Technological rationality thus protects rather than cancels the legitimacy of domination and the instrumentalist horizon of reason opens on a rationally totalitarian society. (ODM, p. 162)
\end{abstract}

With one-dimensionality, we see the human being, with its critical faculties, being devolved to a state of having little or no effective, autonomous critical faculty, subject to a multitude of external, psycho-social influences. These are not just designed and administered by businesses, but also by an amalgam of state institutions. The second-dimension of reason, the one critical of existing arrangements - the "facts" of democracy and freedom - and external voices of authority, had suffered erosion to a point where the "novel feature is the flattening out of the antagonism between culture and social reality through the obliteration of the oppositional, alien, and transcendent elements in the higher culture by virtue of which it constituted another dimension of reality. This liquidation of two-dimensional culture takes place not through the denial and rejection of 'cultural values', but through their wholesale incorporation into the established order, through their reproduction on a massive scale. In fact, they serve as instruments of social cohesion" (ODM, p. 60). Concerning the subject, Marcuse speaks of needs that are false by virtue of being "superimposed upon the individual by particular social interests in his repression: the needs which perpetuate toil, aggressiveness, misery, and injustice" (ODM, p. 7). Technological reality has largely erased the critical individual and its private sphere as "industrial psychology has long since ceased to be confined to the factory" (ODM, p. 12). In this state of play, the concept of alienation loses its grip, as there is little left of the productive and critical self that can be alienated in an overarching, mechanised system of production.

In addition to being subject to the spread of modes of mind associated with mechanisation, "people recognize themselves in their commodities; they find their soul in their automobile, hi-fi set, split-level home, kitchen equipment" (ODM, p. 11), rather than in production itself. Marx's tale of technologically mediated alienation would seem to have reached a depressing climax where the dynamics of alienation appear stunted by a human subject that is objectified by the 
works of its own machines - both their products and demands. This is not aptly described as a big bargain: ${ }^{9}$ security and welfare for restrained criticism and acquiescence. As the subject is "violently defending [its] own servitude" (1967a, p. 80), there is in fact precious little that it can trade in terms of a critical perspective on the matters-of-fact or "a self of one's own".

We have outlined what was spread: a technological rationality vaguely understood as one that means conformity to external, machine-based demands, inspired by Veblen and ultimately, Marx; to what it was spread: the critical, human subject, with its different spheres of existence. In accounting for the mechanisms by which it was spread Marcuse was even less specific, but his astute criticism of the expressions of the advertisement industry suggests that he saw the application of techniques originally developed in the context of industrial and military organisations as the main culprit. That is to say, the human subject was exposed to social organisation inspired by automation and machine work not only in the sphere of work. This mode of organisation also increasingly came to the state and its institutions, and to those charged with marketing the glut of goods coming from post-WWII mechanised production: selling cars, wars, and political candidates by means of intimate knowledge of the human psyche. For purposes of a possible defence and renewal of his thought in the light of developments in cognitive and communication technologies, it is worth separating this empirically oriented Marcuse from the one who engaged with the philosophy of his day.

The empirically oriented Marcuse took over the term "organized capitalism" from Marxist Rudolf Hilferding "to describe the administrative-bureaucratic apparatus which organizes, manages, and stabilizes capitalist society” (Kellner, 1984, p. 233). Marcuse was familiar with Vance Packard's The hidden persuaders (1957). Having a media background himself, Packard made widely known how Ernest Dichter had carried out research in motivational theory and fused it with advertising research, relying on, e.g., depth interview techniques to get consumers "musing absentmindedly about all the pleasures, joys, enthusiasms, agonies, nightmares, deceptions, apprehensions the product recalls to them" (Packard, 1957, p. 31). ${ }^{10}$ However much such criticism of prevailing consumer cul-

9 This term was used by Mumford in his Authoritarian and Democratic Technics (1964).

10 While not wanting to here imply any sweeping condemnation, a contemporary Marcuse would likely have found Fogg's (2003) Persuasive Design interesting, along with the methods and goals of the originally UK state-sponsored Behavioral Insight Team, also known as the nudge unit. A recent source of empirical and theoretical backing for the idea of a besieged, minimised self in the context of work might come from Slaby's (2016) idea of mind invasion, which lets the idea of a social, embodied mind cut both ways: we use the environment to think and feel, but the environment also uses us, as it were. Consequently, they call for a political philos- 
ture reverberated and reverberates, in "From Ontology to Technology", Marcuse insists: "Such an integration [of radical critique and effective opposition into the status quo] cannot be explained by the emergence of mass culture, the organization man or The hidden persuaders etc. These notions belong to a purely ideological interpretation that neglects the analysis of the most fundamental processes which undermine the base upon which a radical opposition might have developed" (2011a, p. 133). If these sociological, psychological, and economic analyses do not reveal the most fundamental processes that render the subject without the potential to negate and oppose the world around him, what does?

In answering this question, Marcuse, in an analysis that appears inspired by the thought of Heidegger, emphasises how the banning of appeals to final causes - a teleological structuring of observations and reality - had spread from post-newton scientific methods to society. Rather than finality, science seeks an “'order' based on calculability and predictability” (2011a, p. 140). The new science "abstracts itself" from the concrete individual and its "sensuous body" (2011a, p. 133). In a critical reading of Quine’s scientifically informed philosophy of language and logic (1953), Marcuse registered how this science treats objects as “obsolete cultural postulates" (Quine 1953, p. 44, cited in Marcuse 2011a, p. 134). Gone are the dualisms in tension that drive dialectics. The natural world had since become a technical world and "technology has replaced ontology" (2011a, p. 134), where Marcuse takes ontology to consist of the Hegelian movement of synthesis of opposites. To Marcuse, humans in advanced industrial societies have, unlike humans in "pretechnological civilization" (2011a, p. 135), lost the ability to live in two dimensions; to view reality from vantage points different from the actual. Rather than facing an unforgiving nature - the original situation we saw Marx initially appeal to - technologically advanced man now faced "the very power of man" through which the technical world "has congealed into a second nature" (2011a, p. 136), more destructive and dangerous than pretechnological, original nature. A corollary to the disappearance of considerations of telos from science is what Marcuse suggests is the common ground between development in sciences and social life: the principle of efficiency. Marcuse sums up: “Consequently, technical reality is deprived of its logos, or, more precisely, that logos appears as deprived of reality, as a logical form without substance. Contemporary positivism, semantics, symbolic logic, and linguistic analysis define and filter the universe of discourse for the use of technicians” (2011a,

ophy of mind. See also Slaby \& Mühlhoff (2018) for an analysis of Post-Fordism work. When moving beyond the workplace, aspects of the idea of the quantified self and its different measuring and motivational practices would likely have attracted Marcuse's interest. 
p. 136). This concerns, not only objects, but also activities and concepts pertinent to workers, where actions are made fit for technicians through their analysis in terms of operations.

\subsection{The missing technics in Marcuse's reception}

So far, I have made a sketch of Marcuse's far-reaching and theoretically rich criticism of advanced, industrial society, culminating with $O D M$. Before we focus further on the role of technology in his criticism, it is worth reflecting briefly on the immediate reception of his thought. While enjoying immense popularity in wider circles, including social and political movements, the academic reception was unfavourable. Perhaps most critically, Marcuse's distinction between technics and technology has been widely neglected. Macintyre, in addition to attempting to argue that “almost all of Marcuse's key positions are false” (1970, p. 2), considered the development of Marcuse's thought to be set apart from "classical Marxism” (1970, p. 17). This way of approaching Marcuse made for a largely misguided presentation of his thought and might have led to oversight of the continuity of focus on production technologies in Marx and Marcuse. ${ }^{11}$

Among futurologists, Marcuse has widely been branded as a pessimist, and eventually, himself a purveyor of the one-dimensional intellectual sound bites that pass for genuine, oppositional thinking. Futurologists tend to focus on technology in their reflections on societal trends and predictions, and they have in Marcuse's writings largely seen the description of human subjects as powerless and impoverished in the face of increasingly complex and fast-paced technologies. An early proponent of this understanding was Toffler's influential Future Shock (1970): “...despite all the anti-technological rhetoric of the Elluls and Fromms, the Mumfords and Marcuses, it is precisely the super-industrial society, the most advanced technological society ever, that extends the range of freedom". Yet, the young mind is "...influenced by a stream of movies...fed by a prestigious line of authors from Kafka and Orwell to Whyte, Marcuse and Ellul [and] the fear of bureaucracy permeates their thought [...]. The fear of being swallowed up by this mechanized beast drives executives to orgies of self-examination and students to paroxysms of protest” (Toffler, 1970, p. 321). Throwing Ellul and Mar-

11 Schatzberg also suggests Marcuse to be a "heterodox Marxist philosopher" (2018, p. 221). This line of interpretation of Marcuse has been the subject of consistent criticism. See in particular Kellner (1984, p. 400) and Gandesha (2004). 
cuse in the same pot of strong anti-technological sentiment, with some caveats, remains a feature of futurology. ${ }^{12}$

While such appreciation of Marcuse's wider thought and his philosophy of technology are understandable in cases where the approach is based on a reading of ODM, the understanding of technology among those that were supposed to be his own - critical theorists - has perhaps been the most damaging. ${ }^{13}$ As suggested, Habermas, the most influential thinker in the critical school amongst the generation following Marcuse's, has had relatively little to say about technology. Instead, he offered a linguistic development of the critical project. With his idea of a colonisation of the lifeworld, with its different spheres, by instrumental reason, he can be seen to have adopted a version of the idea of a certain spread of instrumental rationality that Marcuse also defended. In a 1968 paper dedicated to Marcuse, entitled Technology and Science as Ideology, Habermas initially lauds Marcuse for being the first to make the "political content of technical reason the analytical point of departure for a theory of advanced capitalist society" (1970, p. 85). However, in opposition to this, Habermas goes on to defend a universal, formal concept of technical rationality, which stands in opposition to Marcuse's narrative of technical rationality as an originally liberating force, but in advanced capitalism a rationality that "... protects rather than cancels the legitimacy of domination and the instrumentalist horizon of reason opens on a rationally totalitarian society" (ODM p. 162, cited in Habermas, 1970, p. 85). The very possibility of two-dimensional thought concerning technology would mean at least imagining a different kind of technological rationality. Habermas' argument against Marcuse's position is worth quoting at length:

"[T]here are two kinds of mastery: a repressive and a liberating one” [ODM, p. X]. To this view it must be objected that modern science can be interpreted as a historically unique project only if at least one alternative project is thinkable. And, in addition, an alternative New Science would have to include the definition of a New Technology. This is a sobering consideration because technology, if based at all on a project, can only be traced back to a "project" of the human species as a whole, and not to one that could be historically surpassed. (1970, p. 87)

Habermas expresses agreement and sympathy with Marcuse's position on technology in what he calls its sociological aspects: the spread of a technical form of rationality through spheres that otherwise exhibit a form of rationality foreign to a technical, instrumentalist one. In the paper, he distinguishes spheres of

12 See e.g. Murphy (2016).

13 For the following two paragraphs, compare Feenberg (1999) and Gandesha (2004). 
““work' or purposive-rational action [by which] I understand either instrumental action [governed by technical rules] or rational choice”, (Habermas, 1970, p. 95) which is colonising other spheres of institutional frameworks. These can be characterised by mythical, religious or metaphysical interpretations of reality, and have different norms of linguistic interaction. The colonisation takes place from above, in so far as the state and state-sponsored science and technology (with its own myths) assist in upholding the stability of capitalism, and from below, as rationality appropriate to the increasingly machine-based work spreads among humans. He develops his own version of the adaptation thought, according to which an active adaptation of nature to human needs has been eclipsed by passive adaptation, where various non-technical norms give way to technical ones.

These are thoughts of Marcuse's that Habermas took himself to be placing on a firmer footing. Yet, in the quote above, Habermas opposes Marcuse's position when Habermas suggests that technological rationality is an ahistorical and formal phenomenon, which is not itself amenable to historical development and possible sublation (Aufhebung) in a further stage of history. Relying on the thought of Arnold Gehlen, Habermas suggests that the history of technology is a history of "human species [having] taken the elementary components of the behavioral system of purposive-rational action, which is primarily rooted in the human organism, and projected them one after another onto the plane of technical instruments, thereby unburdening itself of the corresponding functions” (1970, p. 95). Whether or not we find such a biologically inspired account of technology and its development convincing, its character as a historical constant certainly sits poorly with Marcuse's dialectical outlook on man's essence and the possibility of a qualitatively different technology.

To understand Marcuse's contrasting position on the possibility of historical epochs, we return to his notion of "pre-technological man" and how he, in ODM, adds the idea of a post-technological society (ODM, p. 242). It would be uncharitable to interpret, say, the former to describe a presumed proto-human state, where humans are not yet cognizant of tool use. More charitably read, when speaking of technology, Marcuse likely has in mind the specific historical epoch that he suggested characterised advanced industrial societies, again, the subtitle of ODM, with an overarching, machine-like system that places humans thinking, producing, consuming, communicating - in the service of profit seeking and continued economic growth. The mode of production under capitalism is the constant target of criticism in Marcuse's work, in which technologies played a central role in alienation. Habermas sums up Marcuse's position with clarity: 
At the stage of their scientific-technical development, then, the forces of production appear to enter a new constellation with the relations of production. Now they no longer function as the basis of a critique of prevailing legitimations in the interest of political enlightenment, but become instead the basis of legitimation. This is what Marcuse conceives as world-historically new. (Habermas 1970, p. 84, his emphasis)

Habermas' rejection of Marcuse's idea of developments in technology is based on a failure to make a distinction between science and technology. Habermas suggests that if "the peculiar fusion of technology and domination" can only be interpreted as a world project, then "social emancipation could not be conceived without a complementary revolutionary transformation of science and technology themselves” (1970, p. 85). Habermas' implicit reasoning is that social emancipation can be conceived but cannot be tied to a revolutionary transformation of technology. The idea of a revolutionary transformation in science and technology is met with a mix of incomprehension and rejection as a matter of "a secret hope", forms of religious mysticism, ideas of "a fraternal rather than an exploited nature", and, to Habermas, with the characteristic focus on language and communication: Habermas suggests that Marcuse would "impute subjectivity to animals and plants, even to minerals, and try to communicate with nature instead of merely processing her under conditions of severed communication” (Habermas, 1970, p. 86).

Fortunately, this rejection of Marcuse's position was premature, yet instructive. Marcuse's position is at odds with Habermas' assumption that a revolutionary transformation of science and technology cannot take place. In other words, he is taking issue with Habermas' suggestion that science and technology are at bottom ahistorical. While such a claim involves reflection on the relation between science and technology, it suffices to note how Marcuse, reasonably, in many instances separates the use of technologies from that of science, and emphasises the overall social character of technologies: "Pre-technological and technological modes of domination are fundamentally different - as different as slavery is from free-wage labour, paganism from Christianity, the city state from the nation" (ODM, p. 138). These are, as it were, distinct historical modes, one of which Marcuse characterises as "technological" or as that which characterises "advanced industrial society". ${ }^{14}$

14 A world-historically new form of society with a radically different technological orientation than that which characterises industrial society and its capitalism, could be one that is characterised by an overarching concern for the natural environment, rather than exchange value. This was suggested by Marcuse (2005a), and has been discussed by Vogel (1996) and Feenberg (2005, chapter 6). 
What likely causes some confusion among commentators is the failure to notice Marcuse's distinction between technics and technology. Only the former suggests an ahistorical form. This distinction can help us make sense of his claims about pre- and post-technological man and indeed, serve as the instrumentalist underpinnings of Marcuse's optimism in matters of technology. Unfortunately, Marcuse is not entirely consistent in his usage. While Schatzberg (2018) has offered a detailed and insightful study of the varied use of "technics" and "technology" as the former word migrated from Germany to North America and became "technology", he appears entirely dismissive of Marcuse. He casts Marcuse as a technophobic "European philosopher" (2018, p. 166), and apparently misses Marcuse's distinction when suggesting that "Marcuse's understanding of technology was explicitly instrumental” (2018, p. 224). In fact, the opposite is the case. Marcuse's concept of technology emphasised how capitalist values were intimately integrated with the design, use and spread of artefacts as well as machine-like modes of thought. "Technics" was the word used for the instrumental, "ahistorical" aspect of his conception of technology.

Yet, Schatzberg's account of the distinction remains of service. He casts Lewis Mumford as the true heir of Veblen's transformed concept of technology and, in 'Some Social Implications of Modern Technology', Marcuse claims inspiration from Mumford in upholding a distinction between "technics" and "technology" ${ }^{15}$ The distinction, as offered by Marcuse, is relatively simple. Though advanced industrial society imbues artefacts with its values and modes of thought, technical artefacts - technics - can "promote authoritarianism as well as liberty, scarcity as well as abundance, the extension as well as the abolition of toil" (1998, p. 41). In so far as Marcuse's focus is overwhelmingly on the capitalist setting of technics, with its incentives to produce and consume that which machinebased, advanced industrial society offers its subjects, one might well lose sight of the aspect of Marcuse's thoughts on technology that distinguishes it from technics. This is why warnings against what we today would call technological

15 We cannot here trace all the relevant parts of Schatzberg's detailed history of the concept of technology. He finds that "technology” carries a “...contradictory set of meanings [that] continues to dominate its academic use. Depending on how these meanings were deployed, the concept of technology could support either an instrumental or a cultural view. [Veblen] exemplified the use of technology as a liberating concept...]" (2018, p. 118). According to Schatzberg, the German "Technik" that Veblen transposed had both instrumentalist and cultural meanings, and “... Veblen developed his idea of technology into a sophisticated concept that drew from both the cultural and instrumental aspects of Technik" (2018, p. 130). In the work of Mumford that Marcuse cites - Technics and Civilization (1934) - an instrumentalist, German engineering concept of Technik is likely drawn on and the agency of humans in history maintained; also, the idea of the machine as a tool for exercising power over men is maintained. 
instrumentalism in Marcuse's writings co-exist with the suggestion that technics is value-neutral. When arguing about the pervasive influence of capitalism, we read: "Technology, as a mode of production, as the totality of instruments, devices and contrivances which characterise the machine age is thus at the same time a mode of organising and perpetuating (or changing) social relationships, a manifestation of prevalent thought and behaviour patterns, an instrument of control or domination" (1998, p. 41), and later, in "From Ontology to Technology": "One should therefore reject the notion of technical neutrality, which offers a perspective on techniques beyond good and evil and which appears as objectivity itself, susceptible to social usage in all its forms. Indeed, a machine, a technical instrument, can be considered as neutral, as pure matter. But the machine, the instrument, does not exist outside an ensemble, a technological totality," (2011a, p. 136). Such passages emphasise how artefacts, as a matter of fact but not of possibility, are at home in capitalist society, and in this setting, infused with a focus on exchange value. Yet, in ODM, in discussion of Marx's "handmill quip", Marcuse also suggests that "the social mode of production, not technics, is the basic historical factor. [...] The Machine is indifferent towards the social uses it is put to" (ODM, p. 158, my emphasis). If we take Marcuse to uphold his distinction consistently, we can see it at work when Marcuse says that the truth of the neutrality of technics becomes political, in so far as it suggests that technology is neutral. "In my opinion, the neutrality of technology ... is a political concept. ..... technicity requires domination” (2011a, p. 137). Only when read as a claim about technics under technological capitalism can we make sense of such claims. In contrast with Habermas' position, they point to the possibility of a different technology and form the basis of Marcuse's optimism.

\subsection{Marcuse the optimist: the art of living and a new logos of technics}

On the one hand, Marcuse vividly describes a beleaguered modern subject, exposed to a host of sophisticated methods of manipulation and social engineering and further made docile by the pleasant feeling of consumption. In short, the happy consciousness with no prospect of qualitative change in outlook, making pertinent the question raised in ODM: "[H] ow can the administered individuals who have made their mutilation into their own liberties and satisfactions, and thus reproduce it on an enlarged scale - liberate themselves from themselves as well as from their masters? How is it even thinkable that the vicious circle be broken?" (ODM, p. 255). On the other hand, Marcuse is anything but blind 
to the potential of technology in alleviating human suffering and stunted development. In An Essay on Liberation, this is emphasised: "science and technology are the great vehicles of liberation” (1969, p. 12), and in One-Dimensional Man: "Technics, as a universe of instrumentalities, may increase the weakness as well as the power of man" (ODM, p. 240, my emphasis). ${ }^{16}$

In so far as economical and political forces use technics to shape and re-engineer man, Marcuse does not see the potential of a change in the historical mode of production. Again, "escalation of commodity production and productive exploitation join and permeate all dimensions of private and public existence” (1969, p. 17). As humans adapt to these repressive states of affairs, a change is needed in both the infrastructure of society and man, in order to break the "voluntary servitude". Ultimately, such a change will come from the ability of human beings to experience things differently through what he calls a new sensibility, and with a new logos informing technics. Under the aegis of capitalism, the "logos of technics has been made into the logos of continued servitude". Rather, the logos - understood as "law, rule, order by virtue of knowledge" - of technics should be what Marcuse calls pacified existence, opening up "a universe of qualitatively different relations between man and man, and man and nature" (ODM, pp. 163, 171, 239). In this way, Marcuse's continuation of Marx's idea of a revolution and a new stage of civilisational development invites us to consider carefully and critically how technology is perceived, talked about, and the way that use of technologies might influence our attempts to use our imagination.

Will the light gradually dawn, or will there be a bright spark, a historical break offering a leap to a new stage, characterised by a different logos? When Marcuse points to the former, he seems to think that sufficient quantitative change - however insignificant - might eventually add up to a qualitative one. Death by a thousand cuts, typically appealed to in connection with technologically driven erosion of basic rights, delivered by a diffused agency, could also happen to the logos of technics under capitalism and further spur subjects into action. In An Essay on Liberation, he discusses how initiatives ranging “[f]rom the harmless drive for better zoning regulations... to... decommercialization of nature, total urban reconstruction...” (1969, p. 35) might eventually gain sufficient momentum to critically weaken the technological mode of production and lead to "a collapse of work discipline, slowdown, spread of disobedience to rules and regulations, wildcat strikes, boycotts, sabotage, gratuitous acts of non-compliance” (1969, p. 86).

16 Of course, in An Essay on Liberation, Marcuse should have written "technics”, for consistency. 
Another possible factor in the advent of a revolution is the idea of everyday experience of contradictions - the overall irrationality of the apparently rational - that wears at the moral fibre of the subject. At both the outset and conclusion of ODM, Marcuse does much to offer descriptions of everyday experience of production and consumption that aim to expose contradiction and futility. Perhaps best known is his characterisation of the phenomenon of car ownership: "In a way, I feel cheated. I believe that the car is not what it could be, that better could be made for less money. But the other guy has to live too... We have it much better than before. The tension between appearance and reality melts away and both merge in a rather pleasant feeling” (ODM, p. 230). This expresses the hope that to the extent that people experience work and consumption as decreasingly meaningful, they will opt for qualitative change of their role in capitalism and their mode of participation in its technics. Also, Marcuse saw in dispersed political movements across the globe signs of both bureaucratic management and corporate capitalism being strained under pressure from protest. In these movements, initiated not by workers or "kept intellectuals", but by those on the fringe, Marcuse saw different manifestations of what he called the "the great refusal", which is intimately coupled with the ability to "recognize the mark of social repression, even in the most sublime manifestations of technical progress" (1969, p. 11).

Marcuse calls for a return to utopian thought, which in spite of its perceived lack of scientific character, will be a tool for critical, multidimensional thinking. After all, "utopian possibilities are inherent in the technical and technological forces of advanced capitalism and socialism" (1969, p. 14). Conceiving of utopia is the beginning of thinking about a revolution being instigated by a "bright spark". Marcuse offers no one way of conceiving utopia, no one way of fostering the ability to recognise repression and fostering "the awareness of the transcendent possibilities of freedom [that] must become a driving power in the consciousness and imagination which prepare the soil for this revolution" (1969, p. 31). His optimistic thought in particular - his investigation of prospects for change - appears unfocused as it explores different avenues. As Habermas would see use of tools as a constant in species, Marcuse at one point tries to have an organic foundation of morality serve as the guideline for a qualitative change, where he would emphasise an "erotic drive to counter aggressiveness, to create and preserve 'even greater unities' of life” (1969, p. 19). This would be the foundation for solidarity among human beings. Yet, Marcuse also recognises that the human organism responds to its environment and changes accordingly; patterns of response become "ingrown", and this ingrown, second nature of hardened patterns will also be subject to revolution. Biology, conceived as "the process and the dimension in which inclinations, behavior patterns, and as- 
pirations become vital needs which, if not satisfied, would cause dysfunction of the organism" (1969, p. 20), is no firm foundation for Marcuse nor Habermas, but is itself subject to change and possible Aufhebung. Specifically, Marcuse suggests that the need for "possessing, consuming, handling and constantly renewing the gadgets, devices, instruments, engines, offered to and imposed on the people” (1969, p. 20f) has become a biological need in this enlarged sense. As he will say in Counterrevolt and Revolution, nature, too, awaits revolution, and by this he meant both human nature and the environment of humans. The soul of the worker is subject to a "socially engineered arrest of consciousness" (1969, p. 25) and the instinctual structure of the worker is shaped by vested interests.

In Counterrevolution and Revolt and The Aesthetic Dimension, written after the failure of the 1968 revolution, Marcuse justifies looking to aesthetics at a time when the prospects for a wholesale political change looked bleak again: "In a situation where the miserable reality can be changed through radical political praxis, the concern with aesthetics demands justification. It would be senseless to deny the element of despair inherent in this concern" (1978, p. 1). Marcuse is here presenting too narrow a view of his engagement with aesthetics and technology. Analysing different forms of art was a constant throughout Marcuse's writings. Rather than seeing this late, more strongly thematised preoccupation with art as conceding defeat, we should say that Marcuse sees in art a continued concern for both "the soul of the worker" - human consciousness in advanced industrial society - and the preconditions for a radically different society:

Freedom indeed depends largely on technical progress, on the advancement of science. But this fact easily obscures the essential precondition: in order to become vehicles of freedom, science and technology have to change their present direction and goals; they would have to be reconstructed in accord with a new sensibility - the demands of the life instincts. Then one could speak of a technology of liberation, product of the scientific imagination free to project the forms of human universe without exploitation and toil. $(1969$, p. 28)

To Marcuse, this sensibility is a central and overlapping concern of both art and Marxism in the form of critical theory, here expressed in his 1937 "Philosophy and Critical Theory": In "...every act of cognition the individual must once again re-enact the "production of the world"' (2009, p. 111). To see what is not yet present, Marcuse insists on the importance of fantasy; not, however, unrestrained fantasy, and not one based on universal laws of essence, but on "technical limits in the strictest sense. They are prescribed by the level of technological development" (2009, p. 114). It is in combining contemporary technology with a non-degraded imagination that we stand the best chance of answering 
Kant's question, "What may I hope?" That is to say, it is the best form of assistance to a Habermas to see what he couldn't: A "new technology" as something that can surpass the present. Marcuse can offer few specifics for such utopian visions, but they would place technology in a different mode of production. Technology would serve life, and technics would become informed by what Marcuse calls an aesthetic ethos, where the aesthetic becomes a factor in the technics of production.

Relying on Kant's third critique, Marcuse emphasises how senses are productive and creative and have a share in producing images of freedom. Marcuse, like Kant, sees imagination restrained by sensibility and reason, but to reiterate, Marcuse takes reason and sensibility to have been shaped and repressed historically: "The objects which the senses confront and apprehend are the products of a specific stage of civilisation and of a specific society, and the senses in turn are geared to their objects" (1969, p. 43). Thus, the freeing of imagination for projecting new social moralities and new institutions of freedom, has been, and remains, central for qualitative change. A qualitative change that will have to be communicated and discussed with "old words" that have their ordinary home in one-dimensional society and might be in need of a reversal of meaning. In such a setting, Marcuse suggests that art can take on the role of a Kantian regulative idea, presenting humans in a non-alienated state of being, exhibiting qualities that are distinct from those that prevail under advanced capitalism beauty, tenderness, playfulness. ${ }^{17}$

Miles (2012) argues that there is continuity in Marcuse's preoccupation with art that stretches from his intellectual work immediately following his own, minor participation in the failed German revolution, to the writings that are informed by the political pessimism following the 1960s. In the aftermath of the failed revolution and before studying under Heidegger, Marcuse studied the artist novel for his doctorate, and in An essay on Liberation, he considers literature to be the primary form of art. An overarching theme in the novels of e.g. Mann and Goethe was the overcoming of alienation experienced in a bourgeoisie environment where "the artist must overcome this twoness: he must be able to configure a type of life that can bind together what has been torn asunder, that pulls together the contradictions between spirit and sensuality, art and life, artists' values and those of the surrounding world" (Marcuse, The German artist novel, p. 78, cited in Miles, 2012, p. 37). An integral part of this pulling together was the emergence of a new sensibility. Yet, art is a double-edged sword. It runs

17 Again, this would seem to render beauty a non-historic constant, in contrast with Marcuse's overall dialectic outlook. I shall not pursue this further at present. 
the risk of affirming the culture of which it is a part, by being itself an act of production and subsequent commercialisation. Art can relegate the vision of a different technological constitution to mere fantasy.

As already indicated, Marcuse's later thought can appear unfocused as he thinks practically and theoretically about the possibilities of qualitative change in technology - a new overall framing of technics. ${ }^{18}$ Yet, he is consistently continuing the dialectical outlook of Marx's philosophy and its focus on production. He continues both strands of Marx's thinking. One encapsulated by the idea of small quantitative changes - discontent and increased experience of meaninglessness - summing up to an eventual major upheaval for the better. Another strand emphasises the use of imagination as a driver for projecting different possibilities that have the ability to move a sufficient number of people into action. Here, the Marxist call for workers to unite and act becomes an emphasis on the need for practically everyone - whether engaged in productive activities or not to have their imagination refreshed by literary and other modes of art that can project such possibilities. This would allow people to see through and beyond what Marcuse frequently calls "the technological veil" (e.g. ODM, p. 35).

Marcuse's overarching concern for our mental life and our possibilities of expression in a deeply technological environment remains mirrored in countless, more contemporary discussions. While Marcuse would be concerned with the very possibility of critical expression and saying something new with "old words" in advanced industrial society, robotic researcher Sherry Turkle expresses similar concerns as she reflects on the changing nature of the interactions both children and adults have with robots. This is revealed in the recorded responses children and adults have had during and after interaction with relational artefacts - from text-based Eliza in the mid-1960s, over the 1997 Tamagotchi fad to robotic pets like the Furby decades later. Turkle reflects: "These children are learning to have expectations of emotional attachments to robots in the same way that we have expectations about our emotional attachments to people. In the process, the very meaning of the word emotional is changing. [...] Ultimately, the question is not whether children will love their robotic pets more than their animal pets, but rather, what loving will come to mean” (Turkle, 2011a, pp. 68, 74). Turkle describes the different psychological benchmarks - such as "being alive" - for authenticity as a moving target, historically, as we have interacted with different kinds of machines through the decades and evolved in our responses to them. Rather than being consumed with the question of robots' abil-

18 I have not explored Marcuse's reliance on Freud and his notion of surplus repression in a society with potentially little scarcity. 
ities in terms of intelligence and ability to present functional equivalences of $e$.g. emotions, she takes the crucial question to be what we become as we interact with robots in various spheres of life.

Before ending in aporia and anecdote, Turkle's reflections draw on psychology, theology and biology. I point to Turkle's reflections as they help us put Marcuse's struggle to attain a critical stance on technology in perspective. He made clear how technics, originating on the production floor, had spread to different spheres of life and had a debilitating influence on the human subject. To make this case, however, Marcuse saw the need for a benchmark for human subjectivity. Being critical of the influence technologies had on human subjectivity, he naturally sought the benchmark elsewhere - biology, psychology and art. Since Marcuse wrote, this theme has been explored in a number of arenas such as those explored by Turkle. Though at times it can appear like grasping for straws, looking to art, psychology and biology, as Marcuse did, seem reasonable and promising avenues to pursue with the aim of giving sufficient attention and depth to the answers to the questions that technology presented for Marcuse and that remain with us.

\subsection{Marcuse's challenge to value sensitive design in education}

While I have suggested that Marcuse was often empirically informed in many of his discussions, his thought, and the presentation of it here, moves at a high level of abstraction. I want to now point to a specific design where Marcuse's ideas can present a challenge, both at a concrete level of interpretation of empirical data and to the systematisation of design processes that in part recognise and try to implement Marcuse's insights. While Marcuse appears unfocused in his search for an intellectual and moral counterpoint to what he perceived as one-dimensional man under the sway of technology, I suggest he motivated and offered the outlines of what has become known as value sensitive design. Below, we explore one case of value sensitive design, carried out in an educational context.

When Nissenbaum (2001) called for engineering activism in software design and Friedman, Kahn and Boring (2006) spoke of "frontloading ethics" as key to understanding value sensitive design, they were reiterating an idea that had also found an expression in Marcuse. ${ }^{19}$ The driving idea behind value sensitive

19 Recent overviews of the school of design are found in Friedman, Hendry \& Boring (2017) and 
design is that achieving a design that takes into account the ways technologies influence humans and human societies requires the integration of modes of knowledge that are often kept separate by virtue of the institutional anchoring in higher education. Rather than have philosophers and sociologists carry out an after-the-fact assessment of the impact of any given technology, their insights should play a role in the design process before the technology is offered to the public. Accordingly, value sensitive design operates with a tripartite division of modes of knowledge that have roles in a design process and iteratively inform each other. First, conceptual knowledge of e.g. "trust" or "privacy" (currently the most discussed designed-for value) is required if you want to design for one of these values. Second, empirical knowledge is required to ascertain the values that various stakeholders - different users as well as external stakeholders - actually hold, and further investigate if these values are in fact supported as the technology is used. Finally, technical knowledge is needed in order to realise and embody the values in the relevant, technical artefact or system. This involves a translation of values into specific design requirements and is most clearly something that requires the different kinds of knowledge to be integrated in the design of an artefact, such as a piece of software or a design for learning.

This crucial aspect has been explored by van de Poel (2013). Translating from a general value to a more specific norm and then a design requirement, is called a specification, while translating from the specific to the general is a "for the sake of" relation. He illustrates this by using the example of chicken husbandry systems, which involve the values of animal welfare, human wellbeing and environmental sustainability and knowledge drawn from a branch of biology, ethology, as well as other sciences. The first value, animal welfare, is translated into norms concerning living space, litter, perches and presence of laying nests. This can be further specified into a design requirement in terms of square footage available. The result of such a process is a value hierarchy, where different values pertaining to a practice are clarified and, ideally, implemented in the design.

Marcuse was by no means the first to do so, but he very clearly points to the possibility of value sensitive design towards the end of ODM:

...the historical achievement of science and technology has rendered possible the translation of values into technical tasks - the materialization of values. Consequently, what is at stake is the redefinition of values in technical terms, as elements in the technological

Friedman \& Hendry (2019). Though "moral imagination” features in the title of the latter, I suggest the central task of "eliciting values" from stakeholders would benefit from an approach inspired by Marcuse's. 
process. The new ends, as technical ends, would then operate in the project and in the construction of the machinery, and not only in its utilization. (ODM, p. 236)

Marcuse not only offers a clear motivation for value sensitive design. In earlier writings, he makes the suggestion that what is problematic is the lack of this kind of technological rationality. In the sense of materialism just pointed to, we are not material enough: "The oppressive features of technological society are not due to excessive materialism and technicism. On the contrary, it seems that the causes of the trouble are rather in the arrest of materialism and technological rationality, that is to say, in the restraints imposed on the materialization of values" (2001, p. 57). While value sensitive design as a movement originated in software design, it is by no means restricted to this application, and the methods developed have more recently been applied to questions concerning the use of robots in healthcare. A constant theme throughout its development and arenas of application remains the actualisation of values.

With the technical character of repression and one-dimensionality, Marcuse in places emphasises the importance and promise of educating the youth in technical matters. Alongside such guarded optimism, his concerns for education are predictable, in light of the themes of this chapter: the needs of education are dictated by external stakeholders who have an interest in upholding status quo and manufacturing of consent. Education is included in the "totality of machines" (1972, p. 13), and the forms of education that cater for skills of immediate use in productive activities are given priority. Indeed, higher education itself is a matter of production: "Higher Education is called upon to study the 'detailed needs' of the established society so that the colleges know 'what kinds of graduate students to produce"' (1972, p. 28).

Helping people learn is also a matter of design - teachers and related professionals design for learning. ${ }^{20}$ If one were to combine an astute awareness of values in education with a value sensitive design process, this would both hold promise and face challenges. A challenge that is well recognised in the field of value sensitive design is getting potential and actual users to express their values. Accordingly, a range of empirical methods - ranging from those of ethnography over interview to $e$.g. rapid prototyping and testing - have been adopted to help address the empirical aspects of the question. At a general level, a challenge inspired by Marcuse would be whether values that somehow subvert or challenge the status quo would at all find expression among those in the educational system. The school was, after all, identified as an avenue of one-dimen-

20 For an exploration and analysis of this claim, see Dohn and Hansen (2018). 
sionality, and perhaps most clearly a place where socialisation takes place. Further, in so far as expressions of values that run counter to the status quo are expressed, one may worry that "restraints are imposed" on the kind of values they are thought to be expressions of. That is to say, Marcuse would challenge a value sensitive design process both from above - what values are being designed for? and from below: how do we do justice to the expressions of the users as we turn them into something of sufficient generality to count as a value?

There are a few documented cases of value sensitive design processes being carried out in education, and one of the documented examples of using value sensitive design in education can be seen to strengthen the worries we have identified. RAPUNSEL was a game developed specifically for teaching young girls to program computers and was described as a "test bed for how to embody values in a complex, real-world system” (Flanagan, Howe, \& Nissenbaum, 2008, p. 333). The process had three principal investigators representing the philosophical, empirical and technical investigations and forms of knowledge. The values included those laid out in the definition of the project, primarily gender equity; those discovered during the process of the design, such as those associated with different player points of view in a game and reward systems; and those held, consciously or not, by the designers, such as diversity. Finally, the values of the users - girls testing different versions of the evolving game design - were explored. One value that was discovered among users was subsumed under the heading of "subversion". For example, one of the young girls would ask if it was possible to make their programmable game character "run off and die?" (2008, p. 338).

One would need more knowledge of the context to interpret such statements with greater accuracy, but it can be seen to suggest a small act of refusal to play the game at all - to not want to meet the expectations of an educational system that focuses on the skills and knowledge that serve industrial interests and affords status and compensation by virtue of putting such skills to use. One-dimensionality means that the goals and attitudes of the individual are themselves moulded and produced by technical means, with a view to preservation of the status quo and "positive thinking”. Attitudes that seem counter-productive are, if not somehow amenable to productive use, ignored or undermined. To Marcuse, an important avenue for identifying and fostering two-dimensional thought is the act of subversion. He therefore considered it to be of utmost importance that educational systems recognise their political character. Marcuse primarily saw subversive potential in art, but also in fringe social movements of his day and potentially, in education: "Selfliberation is self-education but as such it presupposes education by others. In a society where the unequal access to knowledge and information is part of the social structure, the distinction and the antagonism between the educators and those to 
be educated are inevitable" (1972, p. 47). However, rather than antagonism and refusal, the objection of the young girl was interpreted and translated by the designers into more general values of autonomy, freedom and creativity, and made part of the design for learning to code.

We cannot be certain of the adequacy of this translation and the strength of our challenge to it. Yet, Marcuse's challenge to value sensitive design becomes that of conducting what he would call a metaphysical analysis of values, in the sense that some of them must be seen as containing potential - an essence that seeks to be unfolded. There is a tendency in value sensitive design to see the question of values as predominantly settled by empirical work, which runs counter to Marcuse's insistence on what we called a teleological structuring of observations and reality. Feenberg has expressed this well:

Modern reason flattens out the difference between the essential potentialities of things and merely subjective desires. It declares its "neutrality" over against the essences which govern the earlier technai. Arbitrarily chosen values are placed on the same plane as essences and no ontological or normative privilege attaches to the latter. (Feenberg, 2005, p. 87)

Value sensitive design has taken on the key task of translating values into design requirements and carefully interpreting the values that users and other stakeholders express. It now faces the challenge to entertain a critical discussion of the values that are materialised in technologies in various spheres, as well as the challenge of listening attentively to expressions of such criticism without immediately absorbing the criticism for the very purposes that are being criticised. Education is a craft, one among more technai, that has its inherent goals. Potentialities and values should be judged in that light. One recent suggestion is that the purpose of education - what makes an education good - runs along three dimensions: qualification, in the form of fostering skills, such as those needed for a job market; socialisation, understood as the acquisition of norms and values in the surrounding society, such as a democratic mindset in may Western contexts; and finally, the goal of education is subjectification, briefly put, understood as the opposite of socialisation (Biesta, 2010). In his exposition of subjectification, Biesta draws on ideas from Kant that were also highlighted in our exposition of the fate of the modern subject according to Marcuse. Subjectification means learning to be intellectually self-reliant and exhibiting a fundamental orientation towards freedom. There is much to suggest that Marcuse would highlight the deficit of the materialisation of subjectification in educational technologies, and he would likely resist the idea that this value should be considered on par with the values of convenience, diversity, entertainment or equity in the design of education. 